\title{
Academic Performance as a Function of Level of Aspiration \& Gender - A Comparative Study amongst Different Streams of Education
}

\author{
Anshu Paliwal ${ }^{1 *}$, Dr. Nanda Rathi ${ }^{2}$
}

\section{ABSTRACT}

The present study examines the level of aspiration of students belonging to different streams of education and its impact on academic performance. The sample of the study consisted of 717 students (358 males and 358 females). The age range of the sample was 18 to 19 years.

Tool used for measuring level of aspiration was Level of Aspiration Measure developed by Dr. Mahesh Bhargava and Prof. M A Shah. Goal Discrepancy Score is the difference between aspiration and the achievement on the same trial. The percentiles of marks obtained in the last qualifying exam were treated as an indicator of academic performance. For inferential purpose the data was treated with ANOVA and Scheffe's test of Multiple Comparison. The findings of the study revealed that no significant difference exists between Academic Performance of students with high and low achievers belonging to Engineering and Management streams of education; however there exists significant differences between academic performances of students with high and low Level of Aspiration belonging to Law fraternity; with students showing low Level of Aspiration performing better than students with high Level of Aspiration. There exists no significant difference between academic performance of boys and girls with respect to Level of Aspiration in engineering stream. However, there exists significant difference between academic performance of boys and girls with respect to Level of Aspiration in Management and Legal streams of education. In both the streams girls outshine boys.

Keywords: Academic Performance, Goal Setting Pattern.

If one want to succeed, one need to set goals. Without goals one lacks focus and direction. Setting goals gives long-term vision and short-term motivation. Goal setting not only allows us

\footnotetext{
${ }^{1}$ UGC NET, Gold Medalist, M.Sc (HD), Research Scholar, Department of Human Development, Faculty of Home Science, RTM Nagpur University, Nagpur, Maharashtra (India).

2 Associate Professor, Department of Human Development, Faculty of Home Science, LAD \& SRP College For Women, RTM Nagpur University, Nagpur, Maharashtra (India)

*Responding Author

(C) 2016 I A Paliwal, N Rathi; licensee IJIP. This is an Open Access Research distributed under the terms of the Creative Commons Attribution License (http://creativecommons.org/licenses/by/2.0), which permits unrestricted use, distribution, and reproduction in any Medium, provided the original work is properly cited.
} 


\section{Academic Performance as a Function of Level of Aspiration \& Gender - A Comparative Study amongst Different Streams of Education}

to take control of our life's direction; it also provides us a benchmark for determining whether one is actually succeeding. It focuses on acquisition of knowledge, and helps to organize time and resources so that one can make the very most of one's life. By setting sharp, clearly defined goals, one can measure and take pride in the achievement of those goals, and one can see forward progress in what might previously have seemed a long pointless grind. It will also raise one's self confidence; recognize one's own ability and competence in achieving the goals that one has set.

Studies have shown that specific and ambitious goals lead to a higher level of performance than easy or general goals. As long as the individual accepts the goal, has the ability to attain it, and does not have conflicting goals, there is a positive linear relationship between goal difficulty and task performance.

Rules to be followed for setting goals are: Set Goals that Motivate; Set SMART Goals i.e. Specific, Measurable, Attainable, Relevant, Time Bound; Set Goals in Writing; Make an Action Plan; Stick With It!

Everyone aims at reaching a definite goal or excellence in performance and in doing so; one sets a desire for distinction which has an inner structure known as 'Level of Aspiration' (LOA). Level of Aspiration is usually influenced by two types of factors environmental and personal. Environmental determinants include Parental ambitions, social expectations, peer pressure, culture, social value, competition and group cohesiveness. Personal determinants include wishes, personality, past experiences, values and interests, sex, socio-economic background and racial background.

In early childhood, before the child is old enough to know what his abilities, interests and values are, his aspirations are largely shaped by his environment. As he grows older and is more aware of his abilities and interests, personal factors have a greater influence, but many of his aspirations, his values for example are still environmental in origin.

\section{Goal setting way to academic success}

Academics is that which has to do with school, college studies or learning in other words which designate the intellectual aspect of education particularly the subjects which deal with organized knowledge (Hornby, 1991). Academic performance refers to the performance that falls within a specified standard. The specified standard is usually called a pass mark and the pass mark is a score above average which students are considered having passed and below which students are considered having failed (Tope, 2011).

Goals are powerful, precise statements about one's intentions. They are motivated by plans, dreams and desires, powered by discipline and maintained through commitment. When it comes 
to university studies we know that successful students routinely set achievable academic goals. Goal setting focuses the mind, forces us to be specific, and requires that we learn to prioritize, manage one's time and make a commitment to completing tasks. During the course of one's studies one may encounter procrastination, low motivation, ill health, personal problems, anxiety, depression and self-doubt. In fact, many issues can get in the way of one's personal and academic progress. However, applying the basic strategies of establishing realistic goals, prioritizing tasks, and setting achievable timeframes can be very useful in getting back on track. Successfully achieving one's goals will contribute positively to one's sense of effectiveness as a student, boost one's confidence and encourage one to keep achieving.

\section{REVIEW OF LITERATURE}

Uniyal, M. P. [2007] conducted a research on Co-relation study of level of aspiration and scholastic achievement in relation to sex and caste. The objectives of this study were (i) to analyze how the level of aspiration determined the scholastic achievement of students; (ii) to compare the level of aspiration of high and low achiever students in respect to gender; (iii) to explore the level of aspiration of high and low achiever students, in relation to caste (General category, OBC, SC and ST). By using multistage stratified random sampling technique a sample of 514 male and female, high and low achiever students were selected from 10 higher education institutions. Educational Aspiration Scale developed and standardized by Saxena (1984) was used to collect information regarding level of aspiration. The data were analyzed by using mean median, S.D. and " $t$ " test technique. The findings were; (1) sex and achievement of students do have interactive effects on the level of aspiration. (2) Boys and girls did not differ in their educational aspirations. (3) The high achiever students had a higher level inspiration in comparison to the low achiever students, (4) High achiever students from all caste categories were found to have significantly higher mean scores on educational aspirations in comparison to the low achiever students.

Bork, J. [2008] studied Effects of goal setting on academic achievement. This study was done to examine the effects of two types of goals, assigned and student-selected, on academic achievement. 25 fourth grade students, in a rural Midwestern elementary school, received instruction and utilized specific, measurable, attainable, relevant, and timely (SMART) goals during two separate social studies units. Using checklists, questionnaires, and journals data was collected and analyzed. Results showed students had a significant academic increase while using both types of goals. Their academic performance was most influenced by the use of studentselected goals. Based on these results, educators would benefit from integrating goal setting into their classrooms. 
Dominique, M., Jacob B. H. and Jordan B. P., Robert, O. P. and Bruce, M. S.[2010] investigated whether Setting, elaborating and reflecting on personal goals improves academic performance. In this study the researchers investigated that, whether an intensive, online, written, goal-setting program for struggling students would have positive effects on academic achievement. Students (N 85) experiencing academic difficulty were recruited to participate in a randomized, controlled intervention. Participants were randomly assigned to 1 of 2 intervention groups: Half completed the goal-setting program, and half completed a control task with intervention-quality face validity. After a 4-month period, students who completed the goalsetting intervention displayed significant improvements in academic performance compared with the control group. The goal-setting program thus appears to be a quick, effective, and inexpensive intervention for struggling undergraduate students.

Shinde, V.M.[2011] conducted A study of level of aspiration among tribal children. The objectives of the study were1) to find out the level of aspiration among primary school going tribal children; 2) to find out the relationship between level of aspiration and academic achievement of primary school tribal children. The Sample consisted of 240 tribal girls and 260 tribal boys. The samples were selected randomly from the Primary schools. Aspiration scale developed and standardized by Mahesh Bhargava and M.A.Shah was used to measure the aspiration level among tribal children. For the present study the statistical techniques viz., mean, standard deviation, 't'- test and Co-relation were used for the purpose of knowing the extent of relationship between the variables and also regarding their significant difference. The findings of the study revealed that1) the Primary school tribal Boys and Girls do not differ in the level of aspiration and 2) there is significant relationship between the level of aspiration and academic achievement among the primary school tribal children.

\section{SIGNIFICANCE OF THE STUDY}

In education process there are several factors which influence the academic performance. Among them level of aspiration has special significance, along with parental education, occupation and income. How much a student aspires (the level of aspiration) becomes an essential parameter, when it comes to enhancing the Academic Performance. An academic performance can be taken as how well someone does during his/her academics. This means, how they performed in their school including all the activities that go along with it. The most known indicator of academic performance is the grade. Student joining different streams of education do have different aptitudes. It is essential to know their level of aspiration and how it influences their academic performance. Hence the impact of level of aspiration and gender on academic performance -a comparative study of students belonging to different streams was studied.

\section{Statement of the Problem}

Academic performance is considered to be one of the prime indicators of one's success. Academic performance tells us how an individual will be viewed in his career depending on his 
performance he demonstrates now. Academic performance is being affected by many different variables. Level of Aspiration is an essential process when it comes to increase in Academic Performance. Goal setting helps a student to plan realistic, time bound and clear goals which help in improving grades. How much Academic performance is affected by level of aspiration and Gender is what the researcher intends to study in the present study.

\section{OBJECTIVES}

1. To assess the effect of level of aspiration on academic performance of students belonging to different streams of education.

2. To analyze the impact of level of aspiration on academic performance of boys and girls belonging to different streams of education.

\section{Hypotheses}

1. There is no significant difference in the Academic performance of students with high and low achievers in Engineering Stream.

2. There exists no significant difference in academic performance of boys and girls with respect to level of aspiration in Engineering Stream.

3. There is no significant difference in the Academic performance of students of Management stream with high and low achievers.

4. There exists no significant difference in academic performance of boys and girls of Management Stream with respect to level of aspiration.

5. There is no significant difference in the Academic performance of students with high and low achievers in legal stream.

6. There exists no significant difference in academic performance of boys and girls of Law Stream with respect to level of aspiration.

\section{METHODOLOGY}

The effective sample of study comprised 717 college students. The sex ratio of the sample was 1:1. Random sampling method was used to select the subjects. The age group of the subjects was 18 to 19 years. The students were in first and second year of their graduation. The sample was selected from three different streams of education viz Engineering, Management and Law.

\section{Tool Used}

Tool used for measuring level of aspiration was Level of Aspiration Measure developed by Dr. Mahesh Bhargava and Prof. M. A. Shah. The board results of class XII were used to record data of Academic Performance.

\section{Analysis and Interpretation of Data}

The data was analyzed by using both descriptive and inferential statistical treatment. At the initial stage the data was subjected to descriptive statistics i.e. mean and standard deviation. 
Academic Performance as a Function of Level of Aspiration \& Gender - A Comparative Study amongst Different Streams of Education

Later for the inferential purpose the data was subjected to ANOVA and Scheffe's test of Multiple Comparisons. Wherever it was necessary the findings were presented graphically.

\section{RESULTS AND DISCUSSIONS}

Table 1. Mean \& SD values of Academic Performance of students with respect to level of aspiration belonging to different streams of education.

\begin{tabular}{|l|l|l|l|l|l|l|l|l|}
\hline $\begin{array}{l}\text { S. } \\
\text { No. }\end{array}$ & \multicolumn{2}{|l|}{ Level of Aspiration (LOA) } & \multicolumn{2}{|c|}{ Engineering } & \multicolumn{2}{c|}{ Management } & \multicolumn{2}{c|}{ Law } \\
\hline & & & Boys & Girls & Boys & Girls & Boys & Girls \\
\hline \multirow{2}{*}{$\mathbf{2}$} & \multirow{2}{*}{ High } & Mean & 82.78 & 81.9 & 73.42 & 78.34 & 71.71 & 76.48 \\
\hline & & SD & 7.36 & 6.45 & 8.67 & 10.34 & 8.62 & 7.69 \\
\hline \multirow{2}{*}{ Low } & Mean & 83.94 & 83.79 & 71.57 & 76.34 & 74.37 & 79.59 \\
\cline { 3 - 10 } & & SD & 7.11 & 6.52 & 8.36 & 8.94 & 8.29 & 8.19 \\
\hline
\end{tabular}

A look at the table 1 reveals that there are marginal differences in the mean values of academic performance of high and low level of aspiration of boys and girls belonging to different streams of education. The same is graphically represented in Figure 1.

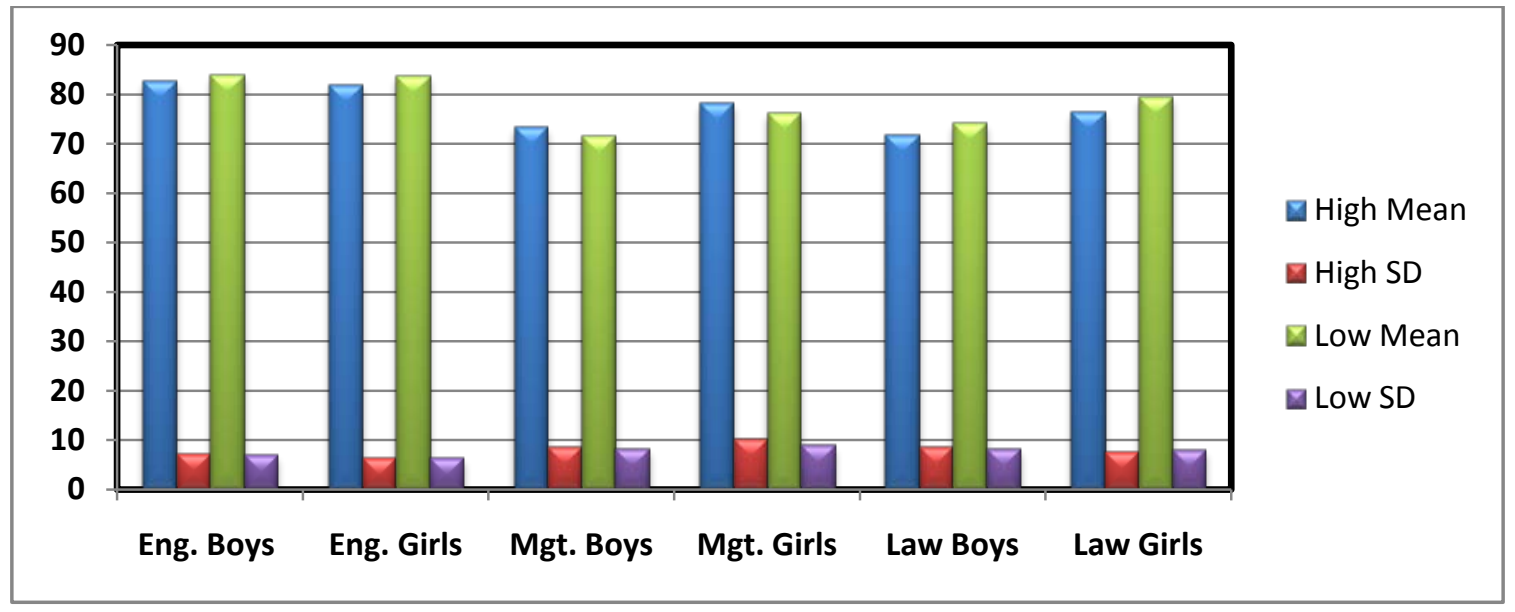

Figure 1 Mean \& SD values of Academic Performance of students with respect to Level of Aspiration belonging to different Streams of education.

Only on the basis of descriptive statistics the data cannot be inferred confidently, hence the data was subjected to two way ANOVA. The complete summary of 2 way ANOVA is displayed in table 2.

Table 2. Complete Summary of two way ANOVA of Academic Performance of students with respect to their Level of Aspiration belonging to Engineering Stream.

\begin{tabular}{|l|l|l|l|l|}
\hline Source & SS & Df & MSS & F \\
\hline A:High Vs Low LOA & 140.3469 & 1 & 140.3469 & 2.97035 \\
\hline B:Gender & 16.0839 & 1 & 16.0839 & 0.340405 \\
\hline A X B (Interaction) & 7.873504 & 1 & 7.873504 & 0.166637 \\
\hline Within & 11150.83 & 236 & 47.24929 & \\
\hline Total & 11315.14 & 239 & 47.34367 & \\
\hline
\end{tabular}

*Significant at 0.05 level **Significant at 0.01 level 
A look at the table 2, clearly shows the calculated value of $\mathrm{F}$ is 2.97 . Table value of $\mathrm{F}$ for $\mathrm{df}$ ( 1 and 236) at $5 \%$ level is 3.88. It means that there is no significant difference in the Academic performance of students with high and low level of aspiration in Engineering Stream. The differences seen can be attributed to the factor of chance. That means for students of Engineering, Level of Aspiration and Academic Performance are independent of each other. Level of Aspiration is influenced by number of factors viz; Parent's education, Parent's occupation, socio-economic status, type of school, family background etc. There are certain other factors that also contribute to academic performance viz study habits, learning styles, test anxiety, self-concept, intelligence etc. Some students score high in last minute of study. However, some plan their study. Other than this, most of the subjects that are studied in class XII get repeated in $\mathrm{I}^{\text {st }}$ year of Engineering with addition of one or two new subjects. This is in contrast to Management and Law subjects, which are altogether different. In engineering stream, it is a revision of the same subject's altogether to form a firm base for moving into specialization. Therefore, it can be, surmised that level of aspiration failed to influence academic performance of students belonging to engineering stream.

The calculated value of $\mathrm{F}$ with respect to gender is 0.34 ; hence it can inferred that there exists no significant difference in academic performance of boys and girls with respect to level of aspiration in Engineering Stream. This could be because the selection criterion in engineering is as it is very high. These days' boys and girls receive equal treatment in society, family and school when it comes to education. This involves going to coaching classes, group study, and discussion method, thus with similar environment it is possible that the boys and girls do not differ in academic performance with respect to level of aspiration in college of engineering.

In order to conclude it can be said that in College of engineering both level of aspiration and gender fail to influence academic performance of college students.

Table 3 Complete Summary of two way ANOVA of Academic Performance of students with respect to their Level of Aspiration Score belonging to Management Stream.

\begin{tabular}{|l|l|l|l|l|l|}
\hline Source & SS & df & MSS & F & \\
\hline A:High Vs Low LOA & 221.7219 & 1 & 221.7219 & 2.669971 & \\
\hline B:Gender & 1406.504 & 1 & 1406.504 & 16.9371 & $* *$ \\
\hline A X B (Interaction) & 0.289815 & 1 & 0.289815 & 0.00349 & \\
\hline Within & 19598.1 & 236 & 83.04281 & & \\
\hline Total & 21226.62 & 239 & 88.8143 & & \\
\hline
\end{tabular}

*Significant at 0.05 level **Significant at 0.01 level

In the above table 3, value of $\mathrm{F}$ is 2.66. Table value of $\mathrm{F}$ for $\mathrm{df}(1$ and 236) at $5 \%$ level is 3.88. This shows that there is no significant difference in the Academic performance of students of Management stream with high and low Level of Aspiration. Students who set high goals 
are over aspirers and those who set low goals are under aspirers. And as regards the field of management is concerned, they have to learn to manage. They have to make the best use of whatever is available to them. Therefore it can be said that level of aspiration (high or low) does not affect academic performance of students belonging to management stream.

The calculated value of $\mathrm{F}$ for the factor $\mathrm{B}$ is 16.93 which is highly significant at 0.01 level. This shows that gender as a factor is significant. Hence it can be deduced that there exists significant difference in academic performance of boys and girls of Management Stream with respect to level of aspiration. In College of Management, girls have shown better academic performance with respect to Level of Aspiration in comparison to boys. It is but obvious as the famous saying goes that girls/ women are good managers and are efficient in multitasking in comparison to boys/men. This has been proved on several occasions, as also with increase of women at work place has become very evident. Hence it can be said that girls show better academic performance with respect to level of aspiration in college of management in comparison to boys.

In order to assess the intergroup mean differences, the data on level of aspiration of student was treated with Scheffe's Test of Multiple Comparison. The values obtained are given in table 4 .

Table 4: Scheffe's Test of Multiple Comparison of Academic Performance of students with respect to their Level of Aspiration (LOA) belonging to Management Stream.

\begin{tabular}{|c|c|c|c|c|c|}
\hline Sr. No. & & $\begin{array}{l}\text { Low } \\
\text { Boys }\end{array}$ & $\begin{array}{l}\text { High LOA } \\
\text { Boys }\end{array}$ & $\begin{array}{ll}\text { Low } & \text { LOA } \\
\text { Girls } & \end{array}$ & $\begin{array}{l}\text { High LOA } \\
\text { Girls }\end{array}$ \\
\hline 1 & $\begin{array}{l}\text { Low } \\
\text { Boys }\end{array}$ & $\mathrm{X}$ & 102.9897 & $683.2072 * *$ & $1372.551^{* *}$ \\
\hline 2 & $\begin{array}{l}\text { High LOA } \\
\text { Boys }\end{array}$ & & $\mathrm{X}$ & 255.6752 & $723.5867 * *$ \\
\hline 3 & $\begin{array}{l}\text { Low LOA } \\
\text { Girls }\end{array}$ & & & $\mathrm{X}$ & 119.022 \\
\hline 4 & $\begin{array}{l}\text { High LOA } \\
\text { Girls }\end{array}$ & & & & $\mathrm{X}$ \\
\hline
\end{tabular}

*Significant at 0.05 level **Significant at 0.01 level

By looking at the mean table 1 along with the above table 4, it can be inferred that, academic performance of girls with low LOA was found to be better than boys with low LOA. Academic performance of girls with high LOA was found to be far better than boys with low LOA. Academic performance of girls with high LOA was found to be better than boys with high LOA. 
It can therefore, be inferred that academic performance of girls is found to be better in comparison to boys with respect to both High and Low Level of Aspiration in college of management. This is because girl's are more serious, they take tasks at hand more seriously and want to give their best. Accordingly, they plan ahead and are goal oriented.

Table 5 Complete Summary of two way ANOVA of Academic Performance of students with respect to their Level of Aspiration belonging to Law Stream.

\begin{tabular}{|l|l|l|l|l|l|}
\hline Source & SS & df & MSS & F & \\
\hline A:High Vs Low LOA & 499.5089 & 1 & 499.5089 & 7.409897 & $* *$ \\
\hline B:Gender & 1494.705 & 1 & 1494.705 & 22.17299 & $* *$ \\
\hline A X B (Interaction) & 3.001607 & 1 & 3.001607 & 0.044527 & \\
\hline Within & 15909.01 & 236 & 67.41104 & & \\
\hline Total & 17906.22 & 239 & 74.92143 & & \\
\hline
\end{tabular}

*Significant at 0.05 level **Significant at 0.01 level

In the above table 5 , the calculated value of $\mathrm{F}$ is 7.40 , significant at $1 \%$ level. Therefore, it can be said that there is significant difference in the Academic performance of students of Law stream with high and low Level of Aspiration. A look at the mean table reveals that students with low level of aspiration show better academic performance in comparison to students with high level of aspiration. Students with low level of aspiration usually are more realistic and they want to play safe. As setting too high a goal and failing to achieve it may lead to disappointment. And law profession altogether needs diplomatic and safe play skills. Therefore, in college of legal studies, students with low level of aspiration show better academic performance than students with high level of aspiration.

From the table 5, it is evident that the calculated value of F 22.17 which is significant at 0.01 level. Hence it can be said that there exists significant difference in academic performance of boys and girls of Law Stream with respect to level of aspiration. Girls of College of Legal studies surpass boys in academic performance with respect to Level of Aspiration. This is because girls are more sincere in their approach towards studies. And being into law field their quest, to know truth and dispense justice is even stronger than boys. Therefore their motivation for pursuing their chosen subject is higher resulting in far greater interest in studies. As studying law and proving and disproving requires a lot of role play and mock set up (like in moot courts) it is easier for girls to relate with it in comparison to boys. This is the reason that girls in COLS perform better in academics with respect to their level of aspiration in comparison to boys.

In order to analyze the intergroup mean differences the data on level of aspiration of student was treated by Scheffe's Test of Multiple Comparison. The obtained values are given in table 6 . 
Academic Performance as a Function of Level of Aspiration \& Gender - A Comparative Study amongst Different Streams of Education

Table 6: Scheffe's Test of Multiple Comparison of Academic Performance of students with respect to their Level of Aspiration belonging to Law Stream.

\begin{tabular}{|l|l|l|l|l|l|}
\hline $\begin{array}{l}\text { Sr. } \\
\text { No. }\end{array}$ & & $\begin{array}{l}\text { Low LOA } \\
\text { Boys }\end{array}$ & $\begin{array}{l}\text { High LOA } \\
\text { Boys }\end{array}$ & $\begin{array}{l}\text { Low LOA } \\
\text { Girls }\end{array}$ & $\begin{array}{l}\text { High LOA } \\
\text { Girls }\end{array}$ \\
\hline $\mathbf{1}$ & Low LOA Boys & X & 212.5341 & $815.8346^{* *}$ & 133.036 \\
\hline $\mathbf{2}$ & High LOA Boys & & X & $1861.178^{* *}$ & $681.8717^{* *}$ \\
\hline $\mathbf{3}$ & Low LOA Girls & & & X & $289.9764^{*}$ \\
\hline $\mathbf{4}$ & High LOA Girls & & & & X \\
\hline
\end{tabular}

*Significant at 0.05 level **Significant at 0.01 level

Looking at the mean table along with the above table 6 it can be construed that, academic performance of girls with low LOA was found to be better than boys with low LOA. Academic performance of girls with low LOA was found to be far better than boys with high LOA. Academic performance of girls with high LOA was found to be better than boys with high LOA. Academic performance of girls with low LOA was found to be better than girls with high LOA.

In order to conclude it can be construed that academic performance of girls is found to be better in comparison to boys with respect to both High and Low Level of Aspiration in College of Legal Studies. More so it is more with girls who set Low Goals. This clearly shows the initial phase of life and risk taking factors. Girl's desires to perform well as also they don't want to take risk, by keeping their aspiration low they outperform boys.

\section{FINDINGS AND CONCLUSIONS}

The findings of the present study from the statistical treatment and analysis of the data revealed the following facts;

1. The findings of the study revealed that level of aspiration failed to influence Academic Performance of students belonging to Engineering and Management streams of education.

2. In Law fraternity, students showing low level of aspiration revealed better academic performance than students with high level of aspiration.

3. There exists no significant difference between academic performance of boys and girls with respect to level of aspiration in Engineering stream.

4. Significant gender differences in academic performances were revealed with respect to level of aspiration in Management and Legal streams of education. In both the streams girls outshine boys.

\section{LIMITATIONS OF THE STUDY}

1. The age group of study was confined to 18 to 19 years.

2. The present study was limited to students of Engineering, Management and Law stream. 


\section{REFERENCES}

Bhargava, M. \& Jain, R. K. (1980), “Personality Correlates of Goal Setting Behavior”, PsychoLingua, Vol. 10 (1), 57-62.

Bhargava, M. \& Shah, M. A. (1971)“Manual for Level of Aspiration Measure”, National Psychological Corporation, Bhargava Bhawan, 4/230, Kacheri Ghat, Agra-282004, India.

Bork, J. (2008), "Studied, effects of Goal Setting on Academic Achievement”. Retrieved fromhttp://viterbo601.weebly.com/uploads/3/1/0/9/31099567/ bork_jeffrey_final_paper_olc_iv_fall_2008.pdf

Dominique, M., Jacob B. H., Jordan B. P., Robert, O. P. \& Bruce, M. S. (2010), "Setting, Elaborating and Reflecting on Personal goals improves Academic performance”. Journal of Applied Psychology, Vol.95 (2), 255-264.

Hornby, A. S. (1991), "Oxford advanced learner's dictionary of current English”. Oxford: Oxford University Press.

Johnbest, W. (1959), “Research in Education”, Engle Wood Cliffs, New Jersey, Prentice Hall.

Kothari, C. R. (2011),“Research Methodology, Methods and Techniques”. Second Revised Edition, New Age International (P) Limited, 4835/24, Ansari Road, Daryaganj, New Delhi-110002.

Shinde, V.M.(2011), “A study of Level of Aspiration among Tribal Children”. International Referred Research Journal,ISSN-0975-3486, RNI: RAJBIL 2009/30097, Vol-II(23).

Tope, O. (2011), "The Effects of study habit on the academic performance of students: A case study of some secondary schools in Ogun State”. Ogun State, Nigeria: Ego Booster Books. Retrieved from https://egoboosterbooks.files.wordpress.com/2011/04/study-habitpdf.pdf

Uniyal, M. P. (2007), "A research on Co-relation Study of Level of Aspiration and Scholastic Achievement in Relation to Sex and Caste". International Referred Research Journal, ISSN-0975-3486, RNI: RAJBIL 2009/30097, Vol-II *Issue 23

\section{Website URL}

https://www.mindtools.com/page6.html

http://www.nationalforum.com/Electronic\%20Journal\%20Volumes/Lunenburg,\%20Fred\%20C.

\%20Goal-Setting\%20Theoryof\%20Motivation\%20IJMBA\%20V15\%20N1\%202011.pdf

https://www.mindtools.com/pages/article/newHTE_90.htm

http://www.usc.edu.au/learn/student-support/health-and-wellbeing/counselling-services/goalsetting-your-way-to-academic-success 